\title{
自然環境下における無拘束ネコの脸単一ニューロン活動の計測と解析
}

\author{
水 谷 好 成*・尾 形 義 徳* - 高 橋 俊 光* - 斉 藤 聡* \\ 中 尾 光 之*・山本 光 璋*・松 本 伍 良**
}

\section{Measurement and Analysis of Single Neuronal Activities from an Unrestrained Cat in Natural Outdoor Conditions}

\author{
Yoshinari Mizutani*, Yoshinori Ogata*, Toshimitsu Takahashi*, Satoshi Saito*, \\ Mitsuyuki NAKAO*, Mitsuaki Yamamoto* and Goro Matsumoto**
}

\begin{abstract}
We have investigated dynamics of single neuronal spontaneous activities in the mesencephalic reticular formation (MRF) of a cat in natural outdoors, using a telemetry system that could measure 7 channels of physiological signals, such as neuronal activity, electroencephalogram, electrooculogram, electromyo gram, and so on. The telemetry system transmits the signals by the method of PDM/FM with about $88 \mathrm{MHz}$ of main carrier. We have successfully recorded long-term spike trains of several single neurons in the MRF. Spectral analyses were carried out on the time series of counts converted from the spike train. The spectrum during waking state outdoors showed a spectral density approximately inversely proportional to frequency (1/f-like spectrum) in the frequency range of $0.01-1.0 \mathrm{~Hz}$. The $1 / \mathrm{f}$-like spectral characteristic during waking state was similar to the one during paradoxical sleep, but clearly different from the white-noise-like spectral profile during slow wave sleep. The $1 / \mathrm{f}$-like spectra observed in the MRF neuronal activities outdoors probably suggest that the neuronal activity displays slow fluctuations both by inputs from the internal/external environments and by dynamics of the MRF neuronal network.
\end{abstract}

Key Words : single unit activity, sleep-wakefulness, biotelemetry, $1 / \mathrm{f}$ fluctuation, field study

\section{1.はじめに}

複雑な情報処理システムである脳の機構を解明するた めに, 外部から刺激を与えその応答を調べる研究が一般 に行われている。しかしながら，脳はニューロンレベル で見たとき，実験者による外的な刺激のない状態でも， いわゆる自発活動”をしている。この活動は, 単一ニュー ロンの自励的な発振，生体内外環境からの制御できない 入力, 神経回路網のダイナミクスなどに基づくものと考 えられるが，その成因を区別することは一般には困難で

* 東北大学情報科学研究科 仙台市青葉区荒巻字青葉

** 北海道工業大学 札幌市手稲町手稲前田 419-2

* Graduate School of Information Sciences, Tohoku University, Sendai

** Hokkaido Institute of Technology, Sapporo (Received December 15, 1992)

(Revised May 26, 1993)
ある、しかるに，その時系列ダイナミクスについては脳 の状態に強く依存することが睡眠生理学分野で明らかに されてきている。したがって，活動のダイナミクスの違 いを明らかにすることは刺激に対する応答特性を調べる 上でもきわめて重要であると考えられる1),2).このような 考え方の下に, 特に本論文では実験室から出て自然環境 下に動物をおいた場合, 脳内の単一ニューロン活動がど のようなダイナミクスを示すかという問題について述べ る.

これまでのわれわれの実験室内での結果によれば，ネ コの中脳網様体, 大脳皮質体性感覚野, 視床腹側基底核, 海馬など, 機能の異なる脳の広範な領域 ${ }^{3)}$ の単一ニュー ロン活動(スパイク時系列)が, 徐波睡眠 (SWS : Slow Wave Sleep) と逆説睡眠 (PS : Paradoxical Sleep) とい う睡眠の 2 状態3)で異なる長時間ダイナミクスを示すこ とが明らかにされている(1) . すなわち, スパイク時系列 
のスペクトル密度が，徐波睡眠時には $0.01 〜 1.0 \mathrm{~Hz}$ の 帯域で平坦な白色雑音様のスペクトルを示すのに対し, 逆説睡眠時にはおおむね同様の帯域で $1 / \mathrm{f}$ 様スペクトル となるという, 上記のいずれのニューロン群にも共通し たダイナミクスの遷移が観測されている3),5).さらに，薬 理学的手法による実験6),8)や, 計算機シミュレーショ ン10),11)によって, その遷移には脳内広域調節系として知 られているアミン系(特にセロトニン系とコリン系) ニューロンの活動が関与していることも明らかにされて いる.これらの実験事実やシミュレーションによって, 神経回路網のダイナミクスの状態依存性がその回路網に 含まれる単一ニューロンのダイナミクスによって代表さ れうる可能性が検証されつつある。一方, 一種の自然刺 激としてネコの眼前に小鳥を呈示し，注意集中させた覚 醒状態においても, 中脳網様体ニューロン活動は $0.1 \mathrm{~Hz}$ 以下の低周波帯域で平坦化する傾向が見られるものの, 逆説睡眠時に類似した $1 / \mathrm{f}$ 様のスペクトルを示すことが 明らかにされている4) 7).

それでは，実験動物であるネコを自然環境下においた とき，脳単一ニューロンはどのようなダイナミクスを示 すであろうか. 白色雑音様スペクトルであろうか. それ とも $1 / \mathrm{f}$ 様スペクトルであろうか. もし $1 / \mathrm{f}$ 様スペクト ルを示すとするとどのような帯域においてであろうか. これらの疑問に答えるため,ここではテレメトリによっ て，屋外において無拘束状態にあるネコの覚醒時におけ る中脳網様体領域 ${ }^{4}$ の単一ニューロン活動を計測し, 解 析した結果を示す。さらにそのの゙イナミクスを同一 ニューロンの睡眠状態における結果と比較する。

\section{2. 実験方法}

ステンレス製微小電極束 $(30 \mu \mathrm{m} \phi$, 微小駆動装置付) と各種生体信号記録用の電極を頭部に植え込んだネコを 実験動物として用いた ${ }^{4)}$.ここでは, 単一ニューロン活動 の計測部位として睡眠-覚醒における脳の状態のダイナ ミクスを最もよく反映していると想像される中脳網様体 領域を選んだ3).中脳網様体は上行性網様体賦活系 ${ }^{12)}$ と呼 ばれ新皮質や旧皮質の覚醒作用に寄与していると見られ ている部位に存在する。この求心性線維は末梢および脳 内の広範な部位から投射され，また，遠心性にも数多く の神経核に線維を送っており脳全体を捉える上でも重要 な部位であり，非特殊系の中心的存在である。さらに睡 眠一覚醒の “意識状態”を判定するために, 眼球運動電位 図(EOG)，大脳皮質体性感覚野脳波(EEG-SI) および外 側膝状体脳波(EEG-LGN), 頸部筋電図 (EMG) および心 電図(ECG)などの生体信号を記録対象とした。

\section{1 屋外・覚醒実験}

屋外の自然環境下におけるニューロン活動の計測は, 大学構内の林内に設置した木枠とナイロン網で作られた $1 \mathrm{~m}^{3}$ 程度の立方体のおり内で実施した，ネコはこのおり 内で自由に行動できる，各種生体信号記録用電極を植え 込んだネコの頭部に，Fig.1(a)に示す送信装置を固定 しテレメータ計測を行った ${ }^{13), 14)}$.

計測された各種生体信号は, Fig. 1(b)に示す 7 チャ

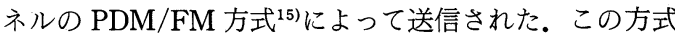
では，2 チャネルの信号 A，Bを交互にパルス幅変調 (PDM: Pulse Duration Modulation)し，パルス波の Low レベル $(\mathrm{L})$ と High レベル $(\mathrm{H})$ の各持続時間が各 信号の変調幅となるようなパルス列を作る、A チャネル には，最も高い周波数成分をもつ単一ニューロンのイン パルス信号を割り当てる。 B チャネルには，インパルス 信号以外の 6 チャネルの生体信号を時分割多重して B 1〜B 6 として割り当てるが，インパルス信号について 周波数帯域の広い筋電図信号をBチャネルの 1 回おき

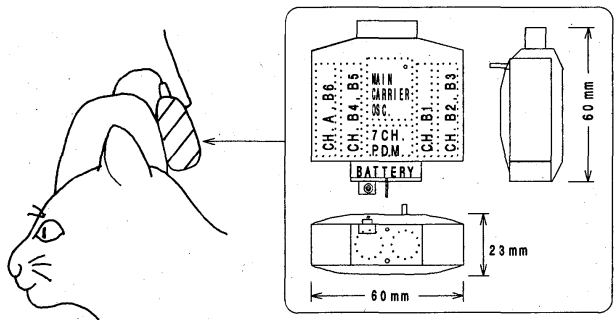

(a) Schema of the transmitter

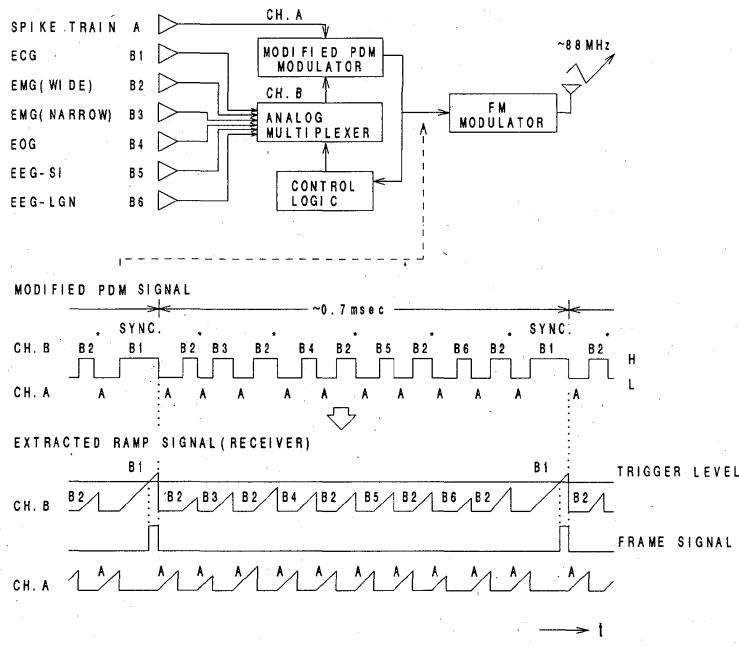

(b) Block diagram of the transmitter circuit, and timing chart of PDM signal

Fig. 1 A transmitter used for telemetry system 
にB 2 として選択するようにする. 10 パルスで 1 周期分 (1フレーム)であり, 各フレームの先頭パルスをほかの パルスと区別するために B 1 信号にオフセットを加えて ある.このように作成した計 7 チャネルの信号成分を もったパルス列をさらに周波数変調(FM : Frequency Modulation)して送信する. 受信側では FM 受信機で復 調されたパルス列信号から, High, Low レベルを別々の ランプ波形信号列, $\mathrm{B}, \mathrm{A}$ チャネルとして取り出す.この $\mathrm{B}$ チャネル信号から，オフセットが加えられている波高 值の高い B 1 信号をトリガレベルで検出し, フレームの 先頭を定める. 使用した送信装置の仕様を Table 1 に示 す.

送信された信号の垂直偏波を，おりの前に設置した フォールデッド・ダイポールアンテナによって受信し, 同軸ケーブルで約 $20 \mathrm{~m}$ 離れた建物の壁を貫通して実験 室内に信号を伝送した ${ }^{14)}$. ついで, FM 受信機, PDM 復 調装置により受信信号を 7 チャネルの信号に復調した。 単一ニューロン活動をスペクトル解析するために，スパ イク信号を矩形波に整形した後コンピュータ (NEC, PC -9801 VM 21)に取り込み, インターバル時系列として光 磁気ディスク (Pioneer, DE-S 701, 片面 300 MB) に連続 記録した。同時に, 波形整形後のスパイク時系列と脳波, 眼球運動電位図などの生体信号はデータレコーダ (TEAC, XR-310)に記録すると共に脳波計(日本電気三 栄(株), $1 \mathrm{~A}$ 57)を用いてペンレコードした.さらに，お りの前に設置したビデオカメラ(Victor, GR-25)を用い てネコの行動を観察し, その映像をビデオデッキ(Toshiba， A-660 HF)によって記録した.

\section{2 室内・睡眠実験}

屋外で計測した同一のニューロンに対して, 徐波睡眠 および逆説睡眠時のスパイク時系列をつぎの手順で計測 した. 消灯した防音電磁シールドルーム内に設置した $50(\mathrm{~W}) \times 60(\mathrm{~L}) \times 70(\mathrm{H}) \mathrm{cm}$ の小型ケージ内にネコを入

Table 1 Characteristics of a transmitter for telemetry

\begin{tabular}{|c|c|c|}
\hline size & \multicolumn{2}{|c|}{$60(\mathrm{~W}) \times 60(\mathrm{~L}) \times 23(\mathrm{H}) \mathrm{mm}$} \\
\hline weight & \multicolumn{2}{|c|}{$55 \mathrm{~g}$ (with batteries) } \\
\hline power supply & \multicolumn{2}{|c|}{ button-type battery $\times 2( \pm 1.5 \mathrm{~V})$} \\
\hline channel & BPF (gain) & signal \\
\hline $\begin{array}{l}\text { Ch. 1(A) } \\
\text { Ch. 2(B 1) } \\
\text { Ch. 3(B 2) } \\
\text { Ch. 4 6(B 3〜 5) } \\
\text { Ch. } 7 \text { (B 6) }\end{array}$ & $\begin{array}{ll}100 \sim 5 \mathrm{kHz} & (63.1 \mathrm{~dB}) \\
0.1 \sim 500 \mathrm{~Hz} & (44.6 \mathrm{~dB}) \\
100 \sim 2 \mathrm{kHz} & (56.1 \mathrm{~dB}) \\
0.5 \sim 100 \mathrm{~Hz} & (69.9 \mathrm{~dB}) \\
0.1 \sim 500 \mathrm{~Hz} & (56.1 \mathrm{~dB})\end{array}$ & $\begin{array}{l}\text { Spike } \\
\text { ECG } \\
\text { EMG } \\
\text { EEG } \\
\text { EOG }\end{array}$ \\
\hline life time & \multicolumn{2}{|l|}{ about 7 hours } \\
\hline modulation & \multicolumn{2}{|l|}{ modified-PDM/FM } \\
\hline carrier & \multicolumn{2}{|l|}{ about $88 \mathrm{MHz}$} \\
\hline sub-carrier & \multicolumn{2}{|l|}{ about $14 \mathrm{kHz}$} \\
\hline
\end{tabular}

れる.ついで, ネコ頭部の電極コネクタに接続した長さ 約 $2 \mathrm{~m}$ の同軸ケーブルを介して単一ニューロン活動・脳 波・筋電図・眼球運動電位図などを導出する。ネコは小 型ケージ内で自由に運動することが可能であり，ほぼ自 然な姿勢で睡眠をとることができる，このような状態で 睡眠-賞醒サイクルのニューロン活動を数時間連続計測 することは容易であった。

\section{3 スパイク時系列のスペクトル解析}

屋外実験，室内睡眠実験で記録したスパイク時系列の 中から解析区間を切り出し，これを一定の時間空(250 ms）における計数值時系列に変換した後, パワースペク トル解析 (Blackman-Tukey 法)を行った。ここでは, ス パイク時系列の $1 \mathrm{~Hz}$ 以下の低周波成分を解析するため に十分なものとして, 時間空を $250 \mathrm{~ms}$ に選んだ4).

\section{3. 計測結 果}

中脳網様体領域内の記録電極の位置を微小駆動装置に よって変え, 単一ニューロン活動を弁別度良く検出でき たニューロンに対して, 屋外・覚醒時および実験室内・ 睡眠時においてスパイク時系列の計測を実施した。本論 文では，1匹のネコにおいて屋外・覚醒状態および睡眠 2 状態において安定な計測ができた 4 個のニューロンに関 する解析結果を示す. 各ニューロンの活動はいずれも 1カ月のオーダで安定であり随時計測されたものである. 最初に一つの例について詳述する。

\section{1 屋外・覚醒状態のニューロン活動}

屋外において計測したポリグラムの連続記録の 1 例を Fig. 2(a)に示す. 各段の上から順に眼球運動電位図 (EOG), 大脳皮質体性感覚野脳波 (EEG-SI), 外側膝状体 脳波(EEG-LGN)，CR 積分回路でアナログ表示した ニューロンの発射頻度時系列(SPIKE), および頸部筋電 図(EMG)である. 1 行は 15 分であり計 75 分間の連続記 録結果である. *印はアーティファクトの混入を示して いる.図示した実験をとおしてネコは比較的おとなしく， 虫や鳥などが現れたとき以外は，ほとんど1カ所に留 まっているか, ゆっくりとした歩行運動をしているかの いずれかであった ${ }^{13)}$. 各チャネルの受信再生波形はアー ティファクトの混入時以外は安定しており，睡眠実験の 場合とほぼ同様の計測が実現できた。

ネコが静かにしている状態でアーティファクトのない 五つの解析区間(OD 1 OD 5) を切り出して, 各スパイク 時系列の性質を調べた。解析区間 OD 1 のポリグラムの 一部を時間軸を引き延ばして Fig. 2(b)に示す。眼球運 動が頻繁，かつ大きいことが EOGからわかる。また EEG-LGNには, 眼球運動に関連したスパイク状の EMP(Eye Movement Potentials)波が観測できる. 

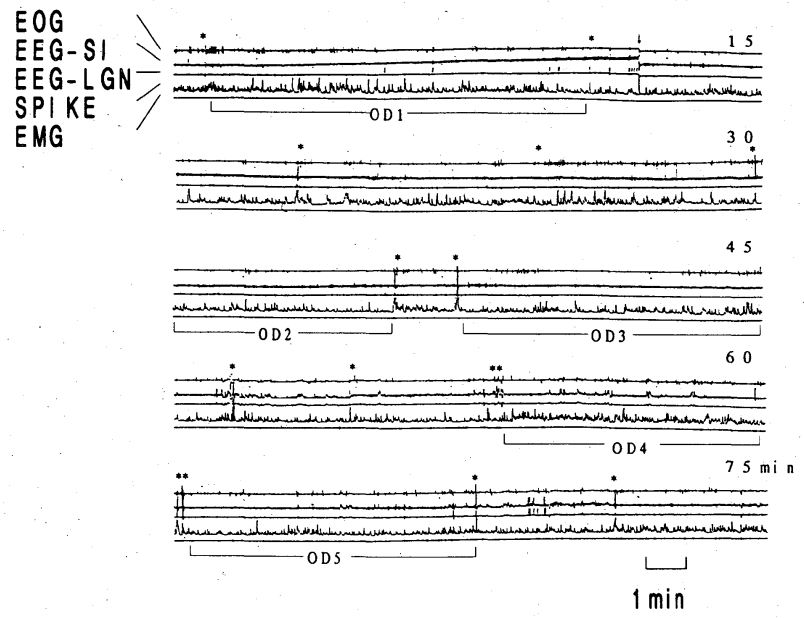

(a) An example of polygraphic records of electrooculogram (EOG), electroencephalogram in somatosensory cortex ( EEG-SI), electroencephalogram in lateral geniculate nucleus (EEG-LGN), spike density process of the neuron (SPIKE) in mesencephalic reticular formation (MRF), and electromyogram of neck (EMG) obtained from a cat in the outdoors

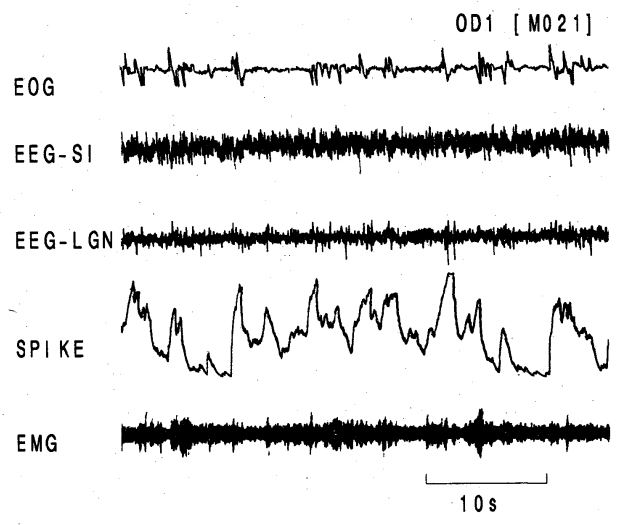

(b) A part of polygraphic records during the analyzed episode (OD1)

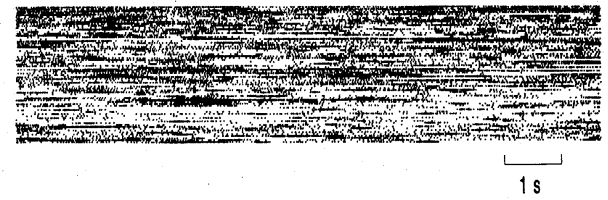

(c) Spike train process of a neuron in MRF during the analyzed episode (OD1)

Fig. 2

EEG-SI には低振幅速波の持続が見られ，高い覚醒状態 が維持されていることがわかる. EMGには持続的緊張 が見られ，虫などを目で追うときや歩行運動の際にバー スト状の活動が見られた。これらはいずれも実験室内で は実現できない状態である，この解析区間のスパイク時 系列を示したのが同図(c)である。図中の一つの点が ニューロンの 1 回の発射に対応し, 時間は左から右, 上 から下へ経過し, 1 行が $10 \mathrm{~s}$ である. 発射頻度に明瞭な低 周波ゆらぎがあることが定性的にわかる。

Fig. 2 の解析区間 OD 1 OD 5 のスパイク時系列のパ ワースペクトル密度を Fig. 3 に示す. 各スペクトルの左
下の数字は平均発射頻度である.いずれも，0.01〜 1.0 $\mathrm{Hz}$ の帯域内で $1 / \mathrm{f}$ 様のプロフィールを示しているが, $0.1 \mathrm{~Hz}$ 以下の低周波帯域においては後述するように解 析区間による変動が大きい.

\section{2 徐波睡眠と逆説睡眠時のニューロン活動}

Fig. 2 と同一ニューロンの活動を記録しながら計測し たポリグラムから, 覚醒 (W), 徐波睡眠(SWS) および逆 説睡眠(PS)状態を逐次的に判定し，3状態の推移を階段 状に示すヒプノグラム(hypnogram)を作成した例を Fig. 4(a) に示す.この中から $\delta$ 波の出現頻度の高い徐 波睡眠相と比較的持続時間の長い逆説睡眠相を解析区間 
として選んだ3). 徐波睡眠時(図中 SWS 1) と逆説睡眠時 (図中 PS 4)のポリグラムの一部とニューロン活動の発 射頻度時系列(SPIKE)を同図 (b)，また各解析区間に対 応したスパイク時系列を同図 $(\mathrm{c})$ ，そのパワースペクト ル密度を同図 (d)に示す。逆説睡眠時にはニューロンの 発射頻度は高くかつ低周波ゆらぎが観測され，そのスぺ クトルは $0.01 〜 1.0 \mathrm{~Hz}$ の帯域においておおむね $1 / \mathrm{f}$ 様 になっている。一方，徐波睡眠時には発射頻度は相対的 に低く, 短いバースト発射はときどき見られるが低周波 ゆらぎはあまり見られず, 0.01〜 $1.0 \mathrm{~Hz}$ の帯域で白色雑 音様のスペクトルを示している。これらの結果はこれま でに報告している中脳網様体ニューロン活動の特性と一 致している ${ }^{4), 9)}$.

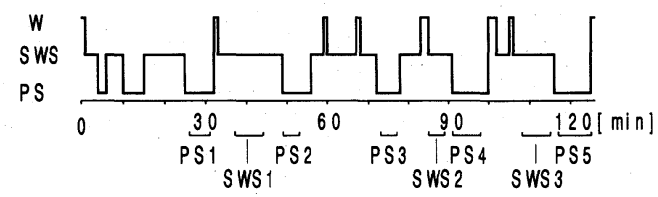

(a) An example of hypnogram measured from a cat indoors

$E O G$

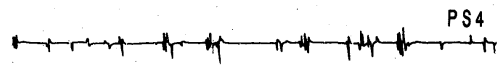

EEG-SI

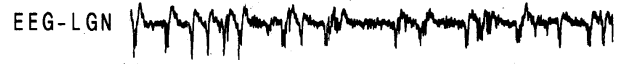

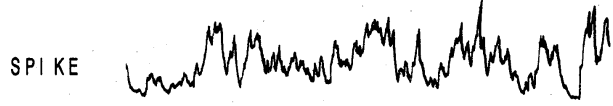

EMG

SWS 1

$E O G$

$E E G-S \mid$

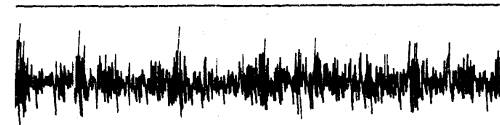

$E E-L G N$

SPI KE

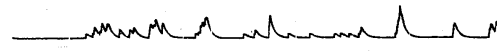

$E M G$

$10 \mathrm{~s}$

(b) Parts of polygram during paradoxical sleep (PS) and slow wave sleep (SWS)
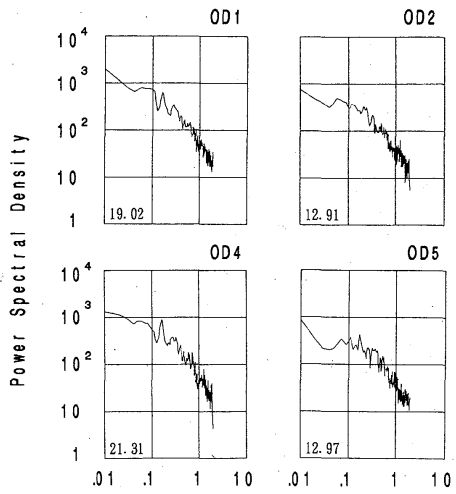

OD5

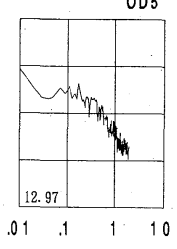

Frequency $[\mathrm{Hz}]$

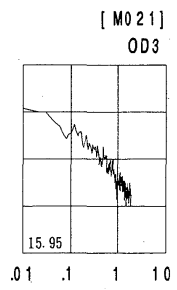

Fig. 3 Examples of power spectral density curve [(spikes $\left./ 250 \mathrm{~ms})^{2} / \mathrm{Hz}\right]$ for a neuron in MRF during the waking state in the outdoors shown in Fig. 2. Mean rates of spikes (spikes/s) are shown at the left bottom of each spectral curve.

PS4

[ MO 21]

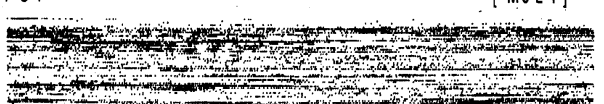

SWS 1

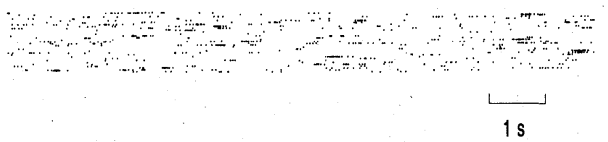

(c) During PS and SWS, examples of spike train process of a neuron in MRF

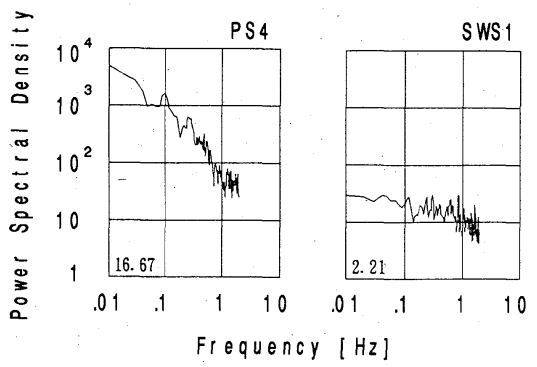

(d) Corresponding power spectral density curve $\left[(\text { spikes } / 250 \mathrm{~ms})^{2} / \mathrm{Hz}\right]$. Mean rates of spikes (spikes/s) are shown at the left bottom of each spectral curve.

Fig. 4 


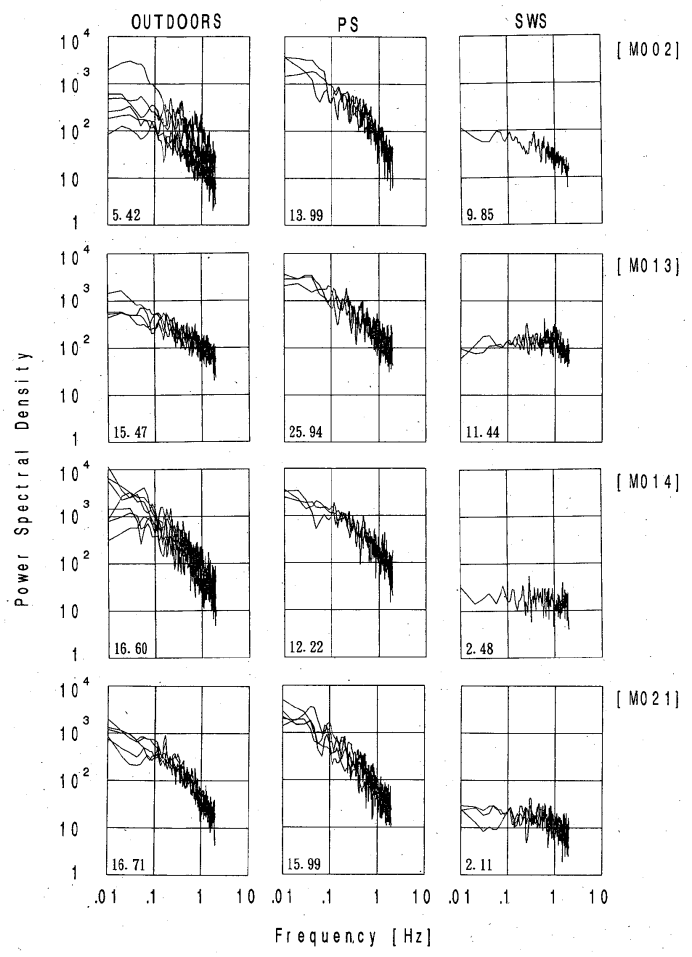

Fig. 5 Power spectral density curves [(spikes $/ 250 \mathrm{~ms})^{2} /$ $\mathrm{Hz}$ ] for 4 neurons in MRF during waking state in the outdoors (OUTDOORS), paradoxical sleep (PS) and slow wave sleep (SWS). Mean rates of spikes [spikes/s] are shown at the left bottom of each spectral curve.

\section{4. 検討}

\section{1 スペクトル密度の比較}

計測した中脳網様体の 4 ニューロンについて，覚醒お よび睡眠の各状態について解析した複数の解析区間のス ペクトルを各ニューロンごとに重ね書きしたものを

Fig. 5 に示す (Fig. 3，4 亿示した例を含む).

まず, $0.1 〜 1.0 \mathrm{~Hz}$ の带域に注目すると, 屋外・覚醒時 と逆説睡眠時においては $1 / \mathrm{f}$ 様スペクトルを大略示して いる：これは，ニューロン，解析区間によらず共通して いる. ただし, 屋外においては解析区間による変動が大 きい.

つぎに, $0.01 \sim 0.1 \mathrm{~Hz}$ の帯域に注目してみると, 逆説 睡眠時にはどの解析区間もスペクトルの傾斜が緩やかに なる傾向を有するものの $1 / \mathrm{f}$ 様の一貫したスペクトルを 示している.これに対し, 屋外ではこの帯域で $1 / \mathrm{f}$ 様を示 すものも見られるが，平坦なスペクトルを示す解析区間 が相対的に多い. 屋外で見られるこの帯域における平坦 化は実験室内で行われた小鳥による注意集中時にしばし
ば見られたスペクトルと類似している5),7)。これは， 10〜100 s の時間スケールでスパイク時系列が定常であ ることを示している16).しかし，この帯域で平坦にならな いスペクトルを示す解析区間(たとえば Fig. 2(a) およ び Fig. 3 に示した OD 5)が見られることは上記の時間 スケールで定常とはいえない区間も同時に多く存在して いることを示している。

また，屋外においては全帯域にわたって解析区間によ るスペクトルプロフィールのばらつきが大きいことがわ かる.これは Fig. 2(a) に見られるように屋外のニュー ロン活動の長時間非定常性を示していると考えられる. 屋外ではさまざまな外的な感覚入力が存在し,動物の“意 識状態”が常に変化している. ある区間では $0.01 〜 0.1$ $\mathrm{Hz}$ で平坦なスペクトルをとるような定常なニューロン 活動を示しながら，別の区間ではこれが非平坦なスペク トルに変化する。これに対し，外界からの入力が遮断さ れている逆説睡眠時には全帯域にわたってスペクトルが 解析区間によらず一貫して $1 / \mathrm{f}$ 様となっている。

逆説睡眠時や屋外・覚醒時に比べると, 安定した徐波 睡眠時には 0.01〜1.0 Hzの帯域にわたって,ぞの ニューロンでもほぼ白色雑音様のスペクトルとなり，明 らかに異なるダイナミクスを示すことがわかる4．

\section{2 調節系ニューロン活動とダイナミクスの関係}

神経系はアミン・コリン・ペプタイドなどのモジュレー 夕と呼ばれる物質群による調節を受けながら活動してい る17).これらのうち大域的な抑制作用を有するアミン(特 にセロトニン)ニューロンの活動状態とここで取りあげ た非特殊系に属する中脳網様体ニューロン活動のダイナ ミクスとを関連付けて考察する。

徐波睡眠時のセロトニンニューロン活動は覚醒時に比 べて低下するものの保持されておりセロトニンが分泌し 続けている.すなわち, 徐波睡眠時には中脳網様体二ュー ロンはその制御を受け，抑制的な状態に置かれていると みなされ3)，そのため低周波ゆらざのない安定した発射 をしていると推測される。

これに対し逆説睡眠時には，セロトニンニューロンは 活動を停止することが知られている18. したがって,中脳 網様体はセロトニンニューロンによる抑制的な制御から 解放されると考元られる。この結果として，中脳網様体 をはじめとする脳内諸部位のニューロン活動が $1 / \mathrm{f}$ ゆら ぎすると考えられる。このことは薬理学的実験6),8 および゙ 計算機シミュレーション ${ }^{11)}$ で証明されつつある。

一方，覚醒時に扔いてはセロトニンニューロンは発射 頻度が最大となる ${ }^{18)}$.したがって,セロトニンニューロン による抑制的作用も最大となることが推測される。しか し，最近の報告によると，低濃度のセロトニンは抑制的 
に働くが，高濃度のセロトニンは興奮作用を有している といわれている.したがって,0.1〜 $1.0 \mathrm{~Hz}$ の带域で一貫

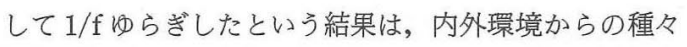
の入力の存在を示唆すると共に, 中脳網様体ニューロン 回路網が覚醒時に有する固有のダイナミクスの特徴を示 していると見られよう。なお，実際にはセロトニンのみ が関与しているのではなく，そのほかノルアドレナリン やヒスタミンなどの調節系ニューロンも関わっていると 考えられる。また，コリンニューロンの活動は覚醒と逆 説睡眠時に高まっていることが知られている6)。した がって，今後これらの物質機構についても検討していく 必要があると思われる。

\section{5. ま と め}

屋外の自然環境下におかれた場合の脳単一ニューロン 活動をテレメトリにより計測し，そのダイナミクスを調 ベた。室内で計測した徐波睡眠，逆説睡眠における同一 ニューロンの活動と比較した結果, 屋外で得られた ニューロンのスパイク時系列のスペクトル密度のプロ フィールは $0.01 \sim 1.0 \mathrm{~Hz}$ の範囲内に朽いて, 逆説睡眠 時と類似した $1 / \mathrm{f}$ 様スペクトルを示すものが多く, 同帯 域で白色雑音様のスペクトルを示す徐波睡眠とは明らか に異なるダイナミクスを示した。睡眠一覚醒状態における 脳内の調節系ニューロンの活動と関連付けると，屋外・ 覚醒時の中脳網様体におけるニューロン活動は調節系 ニューロンの制御下にありながら, 生体の内外環境から の入力と回路網固有のダイナミクスにより低周波ゆらぎ している状態にあると推測される。

本研究の遂行に協力していただいた東北大学情報工学 科生体情報工学講座の大内真理子前技官ならびに学生諸 氏に感謝する。また, 本研究はトヨ夕財団研究助成およ び文部省科学研究費補助金総合研究 (A)04302033に よった。ここに感謝する。なお，本研究は東北大学動物 実験委員会の承認の下に行われた。

\section{参 考 文 献}

1) 山本, 中浜 : 神経インパルス信号の時系列解析とその生理 学的意義, 日本生理誌, 48, 491/504 (1986)

2) 山本光璋: 脳活動のゆらぎと創造機能, 医科器械学, 59 , 109/118 (1989)

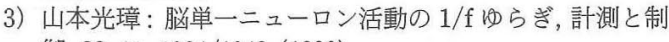
御, 29-11, 1034/1042 (1990)

4) M. Yamamoto, H. Nakahama, K. Shima, T. Kodama and H. Mushiake: Markov-Dependency and Spectral Analyses on Spike-Counts in Mesencephalic Reticular Neurons During Sleep and Attentive States, Brain Res., 366, 279/289 (1986)

5) 山本, 中浜, 嶋, 綾, 児玉, 虫明, 稲瀬: 逆説睡眠時のニュー ロン活動, 神経進歩, 30-6, 1010/1022（1986）

6) H. Mushiake, T. Kodama, K. Shima, M. Yamamoto and H. Nakahama : Fluctuations in Spontaneous Discharge of Hippocampal Theta Cells During SleepWaking States and PCPA-Induced Insomnia, J. Neurophysiol., 60-3, 925/939 (1988)

7) T. Kodama, H. Mushiake, K. Shima, H. Nakahama and M. Yamamoto: Slow Fluctuations of Single Unit Activities of Hippocampal and Thalamaic Neurons in Cats. I. Relation to Natural Sleep and Alert State, Brain Res., 487, 26/34 (1989)

8) T. Kodama, H. Mushiake, K. Shima, T. Hayashi and M. Yamamoto: Slow Fluctuations of Single Unit Activities of Hippocampal and Thalamic Neurons in Cats. II. Role of Serotonin on the Stability of Neuronal Activities, Brain Res., 487, 35/44 (1989)

9) 山本, 水谷, 中尾, 尾形, 高橋: レム睡眠時脳単一ニューロ

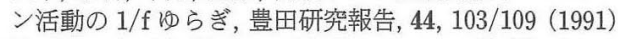

10) F. Gruineis, M. Nakao, M. Yamamoto, T. Musha and H. Nakahama : An Interpretation of $1 / \mathrm{f}$ Fluctuations in Neuronal Spike Trains During Dream Sleep, Biol. Cybern., 60, 161/169 (1989)

11) M. Nakao, T. Takahashi, Y. Mizutani and M. Yamamoto: Simulation Study on Dynamics Transition in Neuronal Activity During Sleep Cycle by Using Asynchronous and Symmetry Neural Network Model, Biol. Cybern., 63, 243/250 (1990)

12) M. Steriade, N. Ropert, A. Kitsikis and G. Oakson: Ascending Activating Neuronal Networks in Midbrain Reticular Core and Related Rostal Systems, J. A. Hobson, M. A. B. Brazier (eds), The Reticular Formation Revisited, Raven Press, 125/167 (1980)

13) Y. Mizutani, M. Nakao, M. Yamamoto and G. Matsumoto: A Telemetry System For Recording Cat's Neuronal Spike Trains During Sleep-Waking States, Proc. 11th Inter. Symp. Biotelemetry, 287/290 (1991)

14）尾形, 高橋, 水谷, 中尾, 山本: 自然環境下における脳幹網

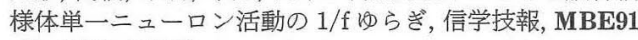
$-61,9 / 16$ (1991)

15) S. Kuriki, Y. Tsuchida, S. Ohta and G. Matsumoto: A Multichannel Telemetry System with a Modified PDM Method, Proc. 7th Inter. Symp. Biotelemetry, 17/20 (1983)

16) 武者, 北原: 1/fゆらぎの物理, 応用物理, 58-12, 1688/ 1695 (1989)

17）前田敏博：アミンおよびコリン作動系ニューロンと脳幹, Clinical Neuroscience, 6, 127/130 (1988)

18) K. Shima, H. Nakahama and M. Yamamoto: Firing Properties of Two Types of Nucleus Raphe Dorsalis Neurons during the Sleep-Waking Cycle and Their Responses to Sensory Stimuli, Brain Res., 339, 317/326 (1986)

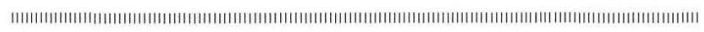

$$
\text { [著 者 紹 介 }]
$$

\section{水 谷 好 成 (正会員)}

1987 年, 北海道大学大学院工学研究科博 士課程修了. $86 \sim 87$ 年度日本学術振與会特 別研究員. 88 年東北大学工学部情報工学科 助手. 93 年同大学情報科学研究科助手. 現 在に至る。単一ニューロン活動の電気的計 測と解析, 神経磁界の計測, 痛みの定量化 などの研究に従事(工学博士)。

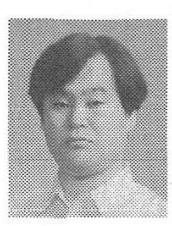


尾 形 義 徳

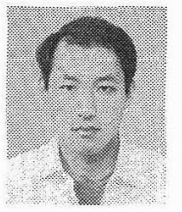

1990 年, 東北大学工学部情報工学科卒 業, 92 年同大学大学院工学研究科博士前期 課程修了(情報工学専攻)。現在,ダイナボッ 卜(株) 総合研究所に勤務。診断システムの 開発に従事。

\section{高 橋 俊 光}

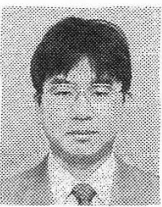

1988 年, 山形大学工学部情報工学科卒 業, 90 年東北大学大学院工学研究科博士前 期課程修了 (情報工学尃攻). 93 年同博士後 期課程単位取得退学. 同年同大学工学部電 子工学科助手. 現在に至る. 生体信号時系 列処理の研究に従事.

\section{斉 藤聡}

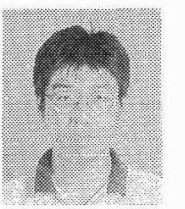

1990 年, 東北大学工学部情報工学科卒 業. 現在, パイオニア (株) 移動体通信研究 所に勤務。

\section{中 尾 光之}

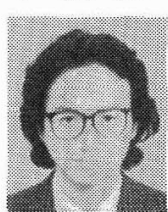

1984 年, 東北大学大学院工学研究科博士 課程修了. $84 \sim 85$ 年東京都老人総合研究所 助手. 85 年東北大学情報処理教育センター 助手. 88 年同大学工学部情報工学科助手, 91 年助教授。93 年同大学情報科学研究科助 教授. 現在に至る。感賞・自律系の電気生
山本 光 璋

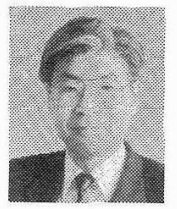

1963 年, 東北大学工学部通信工学科卒 業. 68 年同大学大学院工学研究科博士課程 単位取得退学. 同大学医学部助教授を経て, 88 年工学部情報工学科教授。93 年情報科学 研究科教授. 脳単一ニューロン活動のダイ ナミクス解析と解釈に関する研究で, 実行 系ニューロン活動のレムー徐波睡眠間での 1/f白色ゆらぎの遷移現象を発見している (工学・医学博士).

\section{松本伍良}

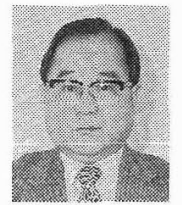

1949 年, 東北大学工学部通信工学科卒 業，同大学工学部助手，助教授を経て，65 年北海道大学応用電気研究所教授, 87 年同 大学名誉教授。現在, 北海道工業大学教授。 医用デバイス，テレメトリ，環境電磁工学 の研究に従事 (工学博士). IEEE, バイオテ レメトリ学会, ME 学会, 電気学会, 応用物 理学会などの会員. 理学的研究, 神経回路網の数理的研究に従 事(工学博士). 